\title{
Workforce Diversity Management Strategies and Organisational Performance in the Food and Beverage Industries in Lagos State, Nigeria
}

\author{
Oyedele Ola Olusegun \\ Department of Business and Entrepreneurship, School of Business and Governance \\ Kwara State University, Malete \\ Issa Abdulraheem \\ Department of Business and Entrepreneurship, School of Business and Governance, \\ Kwara State University, Malete \\ Brimah Aminu Nassir \\ Department of Business and Entrepreneurship, School of Business and Governance \\ Kwara State University, Malete
}

\begin{abstract}
Workforce Diversity Management is gradually being used and becoming acceptable as a significant organizational resource in esteems to whether the objective is to be an employer choice, to offer outstanding customer service, or to sustain a competitive advantage. It also has verified to have controlled to an opinion of being essential for organizational performance especially in the Food and Beverage Industry in Nigeria. This ultimate faith forces managers to hold and understand the theory of workforce Diversity, its benefits and challenges. As such, this study examined the effect impact of workforce diversity management towards organizational performance which focuses into the food and beverage industry within the larger manufacturing sector. The research also emphases on workforce diversity management which contains the employee communication(EC) as a mechanism in reducing conflicts and talent availability(TA) which are the utmost critical variables amongst the others. The study employed primary data mainly for revalidation of results and inferential information from secondary sources. Primary data was harnessed from the views of managers and employees of the foods and beverage industries through questionnaire. The study adopted cross sectional research design and considered 3 multinational corporations in the food and beverage sector in Nigeria based on random sampling technique. The sample size constituted the lower, middle and senior level staff of the multinational Corporations at their headquarters and plants to achieve the objectives of this study based on the two hypotheses that were formulated. Both descriptive and inferential statistical techniques were employed. The statistical tools used included cross tabulations, Mean, Regression and Correlation analysis with the aid of SPSS computer packages. The results showed that employee communication (EC) have significant effect on organizational effectiveness $(\mathrm{OE})$ (at $\mathrm{P}=0.000$ ). It was discovered that talent availability (TA), has significant relationship on employee retention $(\mathrm{ER})($ at $\mathrm{P}=0.002)$, the study reflected that Workforce diversity represents both a challenge and an opportunity for business and corporate entity. Hence, no organization in this dispensation of Globalization can survive without workforce Diversity. The study recommends that; organization ought to accord due priority for optimum utilization of strength of workforce diversity and institute measures to enhance commitment among the employees for improvement of organizational performance. Organizations should make workforce diversity management a core business value because diverse work teams bring high value to organizations and respecting individual differences will benefit the workforce by creating a competitive edge and increasing work productivity.
\end{abstract}

Keywords: Workforce Diversity Management, Talent Availability, Employee Communication, Organizational Performance. 


\subsection{Introduction}

Workforce diversity is the biggest challenge and at the same times the biggest opportunity for the $21^{\text {st }}$ century managers. Diversity management is a strategy to promote the perception, acknowledgment and implementation of diversity in organisations. Workforce diversity has significant implications for the management. The managers will be required to shift their approach from treating each group of workers alike to recognizing differences between and among them and following such policies so as to encourage creativity, improve productivity, reduce labor turnover and avoid any sort of discrimination. Successful management policy and programs will eventually make a huge difference in the communication among employers and the general productivity of the organisation. Todays' organisation needs to recognize and manage workforce diversity effectively(Bhagini\& Swam, 2014).

Workforce diversity management is gradually being adopted in many Nigerian organisations. Even though, there are concerted efforts to invest in workforce diversity management to boost employee morale and performance, organisation rarely achieve their expected benefits. This is because promotion of workforce diversity is also very low among Nigerian institutions given that diversity initiatives have no basis in law in most of the organisations. The theory of social identity and realistic conflict theory (RCT) in the workforce explains that every being has a need of feeling that they belong to a particular group in the society and that most people act in self-interest, workplace being no different (Tajfel, 1982; Sherif, 1996). This sense of belongings gives an individual sense of being part of the organisational system; both formal and informal settings.

The collapse of effective organisational communication had resulted in conflictual relationships within the workforce due to self-interest which are highly inevitable. If the conflict can be managed and controlled, creativity and performance can be increased. Some of the challenges faced in workforce diversity management are political influence, cultural differences, omission of talented workforce due to bureaucracy in a company and majority of the organisations comply with workforce diversity due to legal implications and not general benefit it accords them thus limiting their involvement in diversity management (Shen, Chande, D’Nelto\&Monga, 2009).

A talent shortage that requires to seek-out, and use full capabilities of all employees is urgently required in the Nigerian organisations through the effective workforce diversity management. Workable human resource policies and practices in embracing diversity of workforce is lacking in the assertion of (OSP,2008). Losing talents and employees result in performance losses which can have long term negative effect on companies especially if the departing talent leaves gaps in a company's execution capability and human resource functioning which not only includes lost productivity but also possibly loss of work team cohesion and social good will. It has been noted that spectacular economic growth in India did not come without pain or change of social norms. One of the "causality" has been increased employee turnover. Excessive labour turnover should not be taken lightly as it causes both financial costs and threats to the organisational growth and maturity by increasing system vulnerability and risks. Labour turnover especially of key personnel exposes enterprises to potential risks to their core competence and to the loss of key accounts. Both could result in loss of organisational performance and mounting costs of personnel expenditure. Finally, excessive turnover will have a negative impact on the sustainability of the company.

\section{Research Hypotheses}

In line with the objectives of this study and to answer the various research questions, the following hypotheses which are indicated in their null are postulated between workforce diversity management strategies and organizational performance.

\section{Hypotheses One}

$\mathrm{Ho}_{1}$ : Employee communication does not significantly affect organization effectiveness

$\mathrm{Ho}_{2}$ : Talent availability does not significantly affect employee retention.

http://dx.doi.org/10.19085/journal.sijmd050101 


\subsection{LITERATURE REVIEW}

\subsection{Conceptual Framework}

Workforce diversity management is broadly defined as the systematic and planned commitment by the organisation to recruit, reward and promote a heterogeneous mix of employees (Bagshaw, 2004). The workforce diversity emerged mainly to further the availability equal opportunity philosophy is aimed at ensuring that the organisation make the most out of the differences from a diverse workforce rather than losing talent which might assist the organisation to be more efficient and effective (Bryan, 1999). The effectiveness of an organisation can be measured in different criteria (French, Wendell \& Cencil, 1983) among them is productivity, profits, growth, turnover, stability and cohesion.

\section{Employee Communication in Workforce Diversity Management Strategy}

Training those who are native born help them relate with non-citizens. Training employee to understand the mindset of others help them to look at issues not only through their eye and to help each other through cultural transition as some might go through a culture shock.

Assign mentors and take care of partner that helps the new employee to easily integrate in the system and to be a contributor, effective mentoring is critical and using a person of experience to mentor the new employee who might have come from a different culture enables the person to adapt in to the new culture. The mentor also helps in mediating in situations.(NIWGW, 2011)

Practice open-door communication where employees can feel free to go to meet their senior for advice and guidance. The use of representatives is alright, but in the long run, there are some of the employees who will feel not adequately represented. Those considered senior can also go to their juniors to ask about their opinions or concerns. In this way, communication gap is bridged thus making communication easier.

In company-wide communications, avoid jargons and slang as employee from outside might find it difficult to understand the company communication. Metaphor usage differs across different cultures and what one means might be different from what the other party interprets.

In communication diversity messages, organisation should be able to inform employees why it is important to have an inclusive environment that is harmonious, the benefit they are likely to get, the roles of employees and the strategies on how to enhance diversity at workplace. Key progress and achievements should be highlighted and updates on progress. Should also be passed on through different media, the link communication strategies need to clarify the relationship that exist between diversity management and organisation's mission achievement, (NIWGW,2011). Effective communication build trust and team work between team members. Communication touches every aspect of human activities. Business communication is any communication used to promote a product, service or organisation, with the objective of making sale. In business communication, messages are conveyed through various channels of communication, including internet, print (publication), radio, television, outdoor, and word of mouth.

Communication has been widely accepted by scholars and academics as the lifeblood of an organisation, because communication is needed for exchanging information, exchanging opinions, making plans and proposals, reaching agreement, executing decisions, sending and fulfilling orders and conducting sales (Blalock, 2005; Alyssa, 2006; Kotler, 2006; amongst others). When communication stops, organized activity ceases to exist, and individual uncoordinated activities return in an organisation. So, communication in an organisation is as vital as the blood of life.

Blalock (2005) posits that good communication matters because business organisations are made up of people, and as Robert Kent, former dean of Harvard Business School puts it, "In business, communication is everything".According to Blalock (2005), three reasons why good communication is important to individuals and their organisations are: 1 . Ineffective communication is very expensive. The ability to communicate was rated as the most important factor in making a manager "promotable" by subscribers to Harvard Business Review. 2. The changing environment and increasing complexity of the 21 st century workplace make communication even more 
important. The collaboration that allows organisations to capitalize on the creative potential of a diverse workforce depends on communication. 3. The world's economy is becoming increasingly globalized. According to the management study guide $(1998-2001)$, business communication involves constant flow of information. Feedback is an integral part of business communication. Organisations these days are very large and they involve a large number of people. There are various levels of hierarchy in an organisation. The greater the number of levels, the more difficult is the job of managing the organisation. Communication here plays a very important role in the process of directing and controlling the people in the organisation. There should be effective communication between superiors and subordinates in the organisation, between organisations and the society at large, between management and trade unions, etc. Communication is essential for the success and growth of an organisation. Therefore, communication gaps should not be allowed to occur in any organisation.

Effective business communication helps in building the goodwill of an organisation. Hence, it is necessary that you think before you communicate, be an active listener, be focused on your audience; and in your response, be brief and be gone. According to Alyssa (2006), the ability to communicate, and communicate well is one of the biggest factors in business success. You could be an excellent designer, but if you are unable to promote your services and communicate effectively with clients and colleagues, your potential is limited. The principal areas where communication is essential include: pitching potential clients; clients meeting; consumer service; face-to-face networking; and marketing your business.

All human interactions are form of communication. In this business world, nothing can be achieved without effectively communicating with employers, employees, clients, suppliers, and customers. Business all over the world today is very challenging. To stay profitable in the highly challenging and competitive global market economy all factors at production (i.e. men, machine and materials), should be wisely managed. Among the factors of production, human resource constitutes the biggest challenge because unlike inputs, employee management demands skillful handling of thoughts, feelings and emotions to secure highest productivity. Effective organisational communication plays an important role in this challenge. Communication influence on the perception and opinions about persons, communities, organisations, governments, and even society. As a managerial tool, communication is frequently expected to share information with members, to coordinate activities, to reduce unnecessary managerial burdens and, rules and ultimately to improve organisational performance (Eunju, 2009).

\section{Talent availability and Workforce Diversity}

In todays' competitive and ever-changing business world, retaining and developing talents is central concern of workforce. Workers mobility has become a frequent phenomenon. One reason is a typical characteristics of present workforce, comprising of baby boomers 1946 -1960, Gen X1961 -1980 and Gen. Y 1981 -2000. Baby boomers are nearing retrenchment and Gen $\mathrm{X}$ would be retiring in another few years.

By 2030, 75percent of the global workforce with inherently different personality, attitude, behavior and work values from baby boomers and Gen X (Mohammed \& Lenkia, 2016). Hence, workforce (Talent) availability is a concern to the present world and attending organization.

Talent availability is a systematic process and an organizations commitment to attract, engage, develop, retain top performances in an organization. It comprises of the work processes, activities, strategies, practices and system's that are geared toward developing and retaining a superior workforce. It is about having the right people, matched to the right jobs, at the right time and doing the right thing and in the right place (Devine \& Powell, 2008).

Talent is the core competences of the organization and represents a small percentage of employees. Hasen (2007) posits that talent refers to core employees and leaders that drive the business forward. They are high fliers and inspire others to crave for superior performance. Lewis \& Heckman (2006) suggest that talent availability involves identifying mission-critical values, competences and talents needed in the current and future workforce; clarifying the methods that will be used to recruit, hire, develop, manage and retain high performing workforce.

Understanding the importance of and developing a diverse workforce as a key thing for hiring and retaining the best talent and achieving the desired performance level. This in-fact enhances the problem solving skills and creativity of the organisations. Equal employment opportunity policy requires hiring and retaining workforce without discrimination on grounds of their race, colour, religion, gender etc. and upholding merit. Workforce diversity is a wider concept and includes all similarities and differences among workers. More diversity in management was 
necessary if the need of employees having diverse socio-cultural, ethnic, religious background, age, gender, mental and parental status were to be met.

The word diversity is firstly perceived as giving employment to minorities and affirmative action, but it is not confined to this aspect only. (Jayne \& Dipboye, 2004) it is stated that all those organisations who attach high value to manage diversity are more successful and forward looking. (Jain \& Verma, 1996)

Organisations can succeed at diversity if the initiative to create, manage and value the diverse workforce has the full support of the top management (Hayes, 1999; Jackson, et al, 1992). The following are the HR policies/practices which would make workforce diversity a success in any organisation.

Losing talents and employees result in performance losses which can have long term negative effect on companies especially if the departing talent leaves gaps in a company's execution capability and human resource functioning which not only includes lost productivity but also possibly loss of work team cohesion and social good will. It has been noted that spectacular economic growth in India did not come without pain or change of social norms. One of the "causality" has been increased employee turnover. Excessive labour turnover should not be taken lightly as it causes both financial costs and threats to the organisational growth and maturity by increasing system vulnerability and risks. Labour turnover especially of key personnel exposes enterprises to potential risks to their core competence and to the loss of key accounts. Both could result in loss of organisational performance and mounting costs of personnel expenditure. Finally, excessive turnover will have a negative impact on the sustainability of the company. Attracting, motivating and retaining knowledge workers have become important in a knowledge-based and tight labour market, where changing knowledge management practices and global convergence of technology has redefined the nature of work. While individualisation of employment practices and team-based work may provide personal and organisational flexibilities, aligning HR and organisational strategies for competitive advantage has become more prominent (Horwitz et al. 2003).

According to the Chartered Institute of Personnel Development (CIPD 2006), the changing demographics of the labour market, enduring skills shortages and employee demands for work-life balance have created a so-called 'war for talent'. In this 'war', successful organisations look to improve their strategies, policies and practices for the attraction, development, deployment and retention of talent vital for their business needs. Superior talent is increasingly recognised as the prime source of sustainable competitive advantage in high performance organisations. Underlying this trend is the rapidly changing business environment and the growing need for globally aware managers and professionals with multi-functional fluency, technological literacy, entrepreneurial skills, and the ability to operate in different cultures, structures and markets (Chambers et al. 1998). At the same time, the signs are that attracting and retaining talented employees is becoming harder. In fact, a number of surveys suggest that many large organisations are already suffering a chronic shortage of talented people. Similarly, Sparrow and Hiltrop (1994) alluded to the growing problem of talent shortages in most European countries. In France, for example, the National Institute for Statistics and Economic Studies statistics show that the proportion of manufacturing organisations experiencing difficulties in recruiting all categories of staff rose from 25 per cent in 1976 to nearly 50 per cent by 1989. According to Brewster \& Bournois (1991), the greatest problems are in the managerial and technical labour markets, where the channeling of investment into new computers and machinery, increases in production capacity and new organisation methods have all been associated with a growing requirement for talented people.

Despite the fact that many managers provide their talented employees with competitive remuneration and stimulating work environment, organisations that could be referred to as employers of choice still experience persistent turnover of their talents. The current talent shortage is a reflection of the general shortage of skilled labour and talent supply across skill levels. This phenomenon calls for interventions which go beyond the sphere of influence of a single company. System (macro) level realignments at national level are necessary in order to create adequate competitive factor conditions in India of which human capital remains the most critical factor of today's business environment in India.

Continued education investment has to be one of the India's national development strategy and priority. Short of such public investment, India will not be able to bridge its skill shortage. While the Indian institutes of management (IIMs) enjoy high academic reputation around the world, its annual output of 1,740 graduates cannot meet the demand of India Inc. which requires 2,735, additional managers each year for example (Vorhauser-Smith, 2012). 
An inclusive work environment has proven to attract top talent people and as the result they have been able to retain both employees and the Company's customers. Guthridge et al (2008) noted that buying power, particularly in today's global economy specifically in the 21 st century, is represented by people from all walks of life. More importantly, Companies that interact directly with the public are finding increasingly important to have the makeup of their workforces reflect the makeup of their customer base.

Consequently, the study of Kerby\& Burns (2012)cautious that, businesses and companies that fall to foster inclusive workplaces experience have higher turnover rates than businesses that value a diverse workforce because they foster a hostile work environment that forces employees to leave. The failure to retain qualified employees results in avoidable turnover-related costs at the expense of a Company's profits. Having a diverse and discrimination-free work environment help businesses avoid these costs.

\subsection{Theoretical Background (Diversity Theories)}

\section{Social Categorization Theory (SCT)}

Social categorization theory, by (Tuner, 1987) suggests that people belong to many different social groups (e.g. nation, employer, or school). It predicts that individuals sorts themselves into identity groups based upon salient characteristics and that they act in concert with their categories and favor contexts that affirm group identity (Hogg $\&$ Terry, 2000). In consequence, dissimilar individuals are less likely to collaborate with one another compared to similar individuals. In this way, social categorization may disrupt elaboration of task-relevant information because of possible biases towards in-group members and negative biases towards out-group members. (Knippenberg, Kleef\& De-Dreu, 2007). This is a theory of the self, group processes, and social cognition (Turner et al., 1987) which emerged from research on social identity theory. It is concerned with variation in self-categorization (in the level, content, and meaning of self-categories. It focuses on the distinction between personal and social identity. Social-categorization theory seeks to show how the emergent, higher-order processes of group behavior can be explained in terms of a shift in self-perception from self-categorization in terms of personal identity to selfcategorization in terms of social identity.

\subsection{EMPIRICAL FINDINGS}

In the study of inclusive and harmonious work places conducted by the ministry of man power (MOM, 2010) 87\% of companies' survey agreed that workplace harmony was important to business outcomes. Research has shown that well managed diverse teams out perform homogeneous teams as they tends to be more creative and effective at problem solving. However, when diverse teams are not managed well, communication and trust can break down resulting in lower performance. Greater employee engagement leads to reduced turnover. A 2008 study by Galling management group in the United-States reveal that engaged employee had 51\% lower turnover on average. Han's. F. and B. Pte Ltd operate a chain of bakeries full service restaurant and cafes in response to labour shortages and other operational challenges, Han's diversity management strategy has brought business success within a span of three years, the productivity of Han's workers has increased by $40 \%$ and the net earning per wage dollar have more than doubled. Han's deputy general manager also shared that having an inclusive workplace improves employee engagement- staff absenteeism is extremely low and staff turnover has dropped five folds between 2006 - 2009. The information and decision making perspective is presented by Cox \& Blake (1991), who proposed this [perspective as a theoretical means of understanding the links between organisational diversity and organisational effectiveness. They observed that up to that time, the literature available had asserted a link between organisational diversity and organisational effectiveness (and some studies had demonstrated this link using field studies of empirical finding) (Cox \& Blake 1991). However, name of these studies had actually proposed or tested a casual mechanism associated with this link, instead leaving this issue open to interpretation. The information processing and decision making perspective effectively encapsulates the cognitive resource diversity theory, which posits that the cognitive resources of each team member contributes to the overall success of the team; therefore, a diversity of the cognitive resources promote creativity and decision making capacity (Horwitz, 2005). There is evidence from a wide variety of team 
types, including flight crews and virtual teams support. This framework of understanding diversity in teams (Guzzo \& Dickson, 1996). However, this framework is often only explored in the team context and does not move beyond the team into the organisation as a whole (Van-Knipperberg \& Schippers, 2007). Cox \&Blake (1991).Proposed that cultural diversity would impact six direct aspect of organisational effectiveness including the capability to attract human resources, cost, the issues of innovation, creativity and problem solving, the marketing advantages of a diverse workforce, and organisational flexibility. These six elements were revealed in terms of the major literature of the period. For the information and decision making perspective, the most relevant domain studied by the authors were innovation and creativity, problem solving capacity, and organisational flexibility. The authors' argument regarding these three perspectives can be summarized as follows. Creativity and innovation can be aided by "diversity of perspectives and less emphasis on conformity to the norms of the past" (Cox \& Blake, 1991). Which will increase ability of the organisation to create and innovate. The problem solving argument holds that better decisions would be produced through more perspective inherent in heterogeneous problem solving groups. (Cox \& Blake, 1991).finally, the flexibility argument indicate that multicultural management practices would result in changes that meant "that the system will become less determinant, less standardized, and therefore more fluid" (Cox $\&$ Blake, 1991).these changes are likely to increase the ability of the organisation to react to changing environments. Cadrain (2008) discusses why firms are embracing diversity and argues that encouraging diversity is a positive motivational tool that can attract and retain the best employee as well as increased the level of organisational competitiveness. Success of any organisation relies on the ability to manage a diverse workforce that can bring innovative idea, perspectives and views to their work. The challenge of workplace diversity can be turned into strategic organisational assets if an organisation is able to capitalize diverse talents. With the mixture of talents of diverse cultural backgrounds, gender, ages, and lifestyles, an organisation can respond to business opportunities more rapidly and creatively (Cox, 1993). Organisations can succeed at diversity if the initiatives that create, manage and value diverse workforce has the full support of the top management (Hayes, 1999). Many of these business organisations have identified the significance of maintaining a workforce that truly reflects the diverse nature of the contemporary society of the twenty-first century.

\subsection{METHODOLOGY}

The study adopted descriptive survey with a structured questionnaire developed to gather information from four hundred (400) employees from top three companies in the food and beverages industries in Lagos. A structured questionnaire titled "Workforce Diversity Management and Organisational Performance" was administered to top management, middle staff and lower cadre staff of the top three foods and beverage in Lagos. Out of four hundred (400) questionnaires administered three hundred and seventy (370) representing 92.5\% return and properly filled and analyzed. The study had a scale that comprised of 20 items developed by the researcher from reviewed literature and was validated. Efforts were made to ensure that respondents to the research instrument understand what the instrument wanted from them. Multiple regression and correlation analysis were the statistical tools adopted for analysis with the use of SPSS 15.0. However, the regression analysis was used to determine the cause and effect relationship that existed between workforce diversity and organisational performance. The reliability test indicated a Cronbach's Alpha of 0.6535.

\subsection{Descriptive analysis}

\section{Demographic Characteristics of Respondents}

The respondents were asked to respond to a series of questions about themselves and the organization.

The frequency distribution of the respondents' demographic characteristics is presented in table 4.2 below. The table shows that out of the three hundred and seventy (370) respondents, $196(53.0 \%)$ are male, while $174(47.0 \%)$ are female. By implication, we have more male respondents to female respondents in the sample. Also, there are 70 M.Sc and M.BA holders (18.9 per cent), $15 \mathrm{HND/BSc}$ holders (4.1 per cent), 35 PGD holder (9.5 per cent), in the sample 167 (18.1) and $\mathrm{PhD} 183$ (49.5). By implication, the respondents have high BSc educational qualifications. 
In addition 15 employees (4.1\%) have in the organizations between 1- 5years, 6 -10years 110 (29percent), 11 15years 137 (37percent), 16 -20years 92 employees (24.9percent) and above 20years 16 employees (4.3percent). Again, out of the three hundred and seventy (370) respondents, 48 (13percent) 51 years and above, $180(48.9 \%)$ are between 41 and 50 years of age, 133 (35.9\%) are between 31 and 40 years, and $9(2.4)$ are between 20 and 30 years. By implication most of the respondents are between the age of 41 and 50 years.

More importantly, out of the 370 respondents, 129 (34.6\%) are top level managers; 191 (51.6\%) are middle level managers while $50(13.5 \%)$ are lower level managers. By implication, we have more of middle level managers as respondents in the sample.

Table 1: Frequency Distribution of the Respondents' Demographic Characteristics $(\mathbf{N}=\mathbf{3 7 0})$

\begin{tabular}{|c|c|c|c|c|}
\hline Characteristics & Category & Frequency & Percent & Cumulative percen \\
\hline \multirow[t]{2}{*}{ Gender } & Male & 196 & 53.0 & 53.0 \\
\hline & Female & 174 & 47.0 & 100.0 \\
\hline \multirow[t]{5}{*}{ Educational Qualification } & BSC & 15 & 4.1 & 4.1 \\
\hline & $\mathrm{BSc}$ & 35 & 9.5 & 13.5 \\
\hline & MSC/MBA & 70 & 18.9 & 32.4 \\
\hline & PHD & 183 & 49.5 & 81.9 \\
\hline & OTHERS & 167 & 18.1 & 100 \\
\hline \multirow[t]{4}{*}{ Age } & $20-30$ & 9 & 2.4 & 2.4 \\
\hline & $31-40$ & 133 & 35.9 & 38.4 \\
\hline & $41-50$ & 180 & 48.9 & 87.0 \\
\hline & $51-60$ years above & 48 & 13.0 & 100.0 \\
\hline \multirow[t]{5}{*}{ Period of Service } & $1-5$ years & 15 & 4.1 & 4.1 \\
\hline & $6-10$ years & 110 & 29.2 & 33.8 \\
\hline & $11-15$ years & 137 & 37.0 & 70.8 \\
\hline & $16-20$ years & 92 & 24.9 & 95.7 \\
\hline & Above 20years & 16 & 4.3 & 100.0 \\
\hline \multirow[t]{3}{*}{ Management Cadre } & Lower level & 50 & 13.5 & 13.5 \\
\hline & Middle level & 191 & 51.6 & 65.1 \\
\hline & Top level & 129 & 34.6 & 100.0 \\
\hline
\end{tabular}

Source: Author's Fieldwork Computation, 2017 


\subsection{Statistical Testing of Hypotheses}

\section{Test of Normality}

A normal curve could be drawn to test for normality of the dependent variable (i.e. organizational performance coefficient which are represented by organizational effectiveness and employee retention). Fig to presents a normal curve of organisational performance co-efficient scores. Many of the parametric statistics assume that the scores on each of the variables are normally distributed (i.e. follow the shape of the normal curve). In this study, the scores are reasonably normally distributed, with most scores

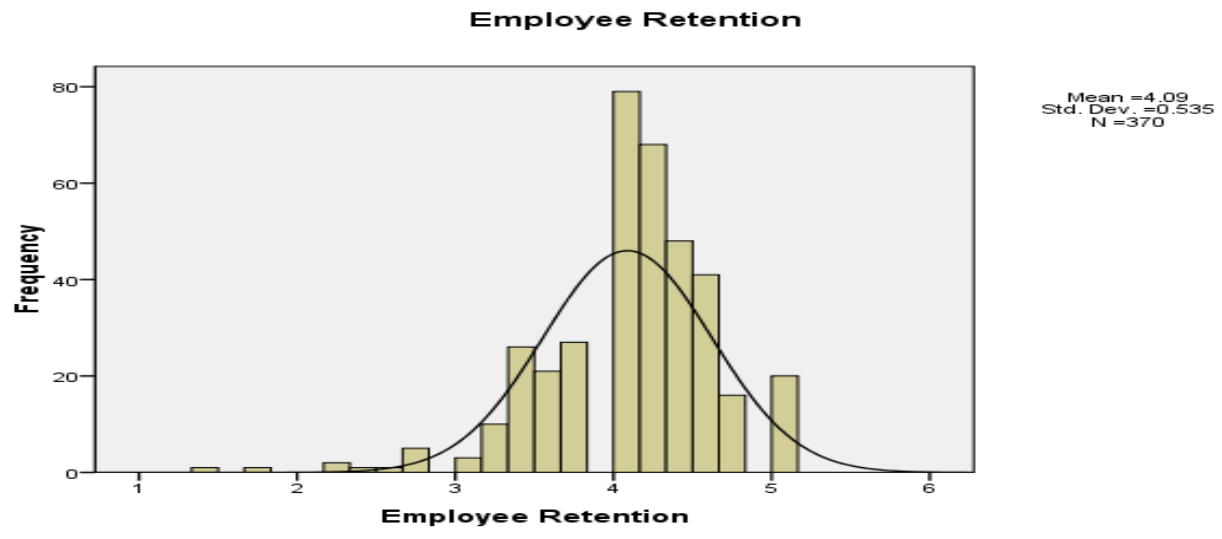

Fig 4.4.1.1: Histogram of organizational effectiveness

Source: Author's Fieldwork Computation, 2017

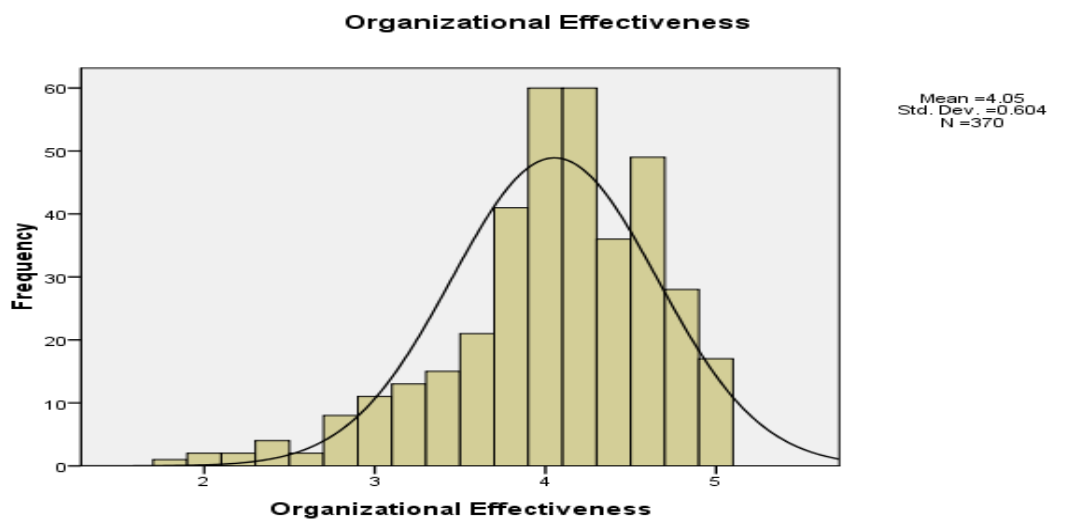

Fig 4.4.1.2: Histogram of Perceived employee retention Scores Source: Author's Fieldwork Computation, 2017

\subsubsection{Test of Multicollinearity}

Multicollinearity exists when the independent variables are highly correlated (that is $r=.7$ and above). Tabachnick and Fidell (2001) suggested that you 'think carefully before including two variables with a bivariate correlation of, 0.7 or more in the same analysis'. There is need to consider omitting one of the variables. To check for multicollinearity, bivariate correlation was conducted in Table below. In the table, the highest correlation was .370. It shows low multicollinearity problem between Workforce Diversity variables (employee communication and talent availability). Therefore, all the variables are retained. 


\begin{tabular}{|c|c|c|c|}
\hline \multicolumn{1}{|c|}{ Table 4.4.2.1:Correlations among Workforce Diversity Variables } \\
\hline & & $\begin{array}{c}\text { Employee } \\
\text { Communication }\end{array}$ & $\begin{array}{c}\text { Talent } \\
\text { Availability }\end{array}$ \\
\hline Employee Communication & $\begin{array}{c}\text { Pearson } \\
\text { Correlation }\end{array}$ & 1 & \\
\cline { 2 - 4 } & Sig. (2-tailed) & & \\
\cline { 2 - 4 } & $\mathrm{N}$ & $.370^{* *}$ & \\
\hline Talent Availability & $\begin{array}{c}\text { Pearson } \\
\text { Correlation }\end{array}$ & 0.369 & 370 \\
\cline { 2 - 4 } & Sig. (2-tailed) & 0.00 & \\
\cline { 2 - 4 } & $\mathrm{N}$ & 370 & \\
\hline \multirow{2}{*}{$* *$ Correlation is significant at the 0.01 level (2-tailed). } & \\
\hline
\end{tabular}

Source: Author's Fieldwork Computation, 2017

\subsubsection{Test of Homoscedasticity and Linearity for Hypothesis One}

A scatter plot could be drawn to test for homoscedasticity and linearity of the relationship between dependent variable i.e. organizational effectiveness and independent variable i.e. employee communication. Fig present the output of scatter plot. From the output below, there appears to be a moderate, positive correlation between the variables. Respondents that are highly affected by employee communication experience high levels of organizational performance factor of organizational effectiveness. On the other hand, employees with less affected by employee communication have much higher levels of organization performance factors. There is no indication of a curvilinear relationship (test of linearity) and the scatter plot shows a fairly even cigar shape along its length (test of Homoscedasticity).

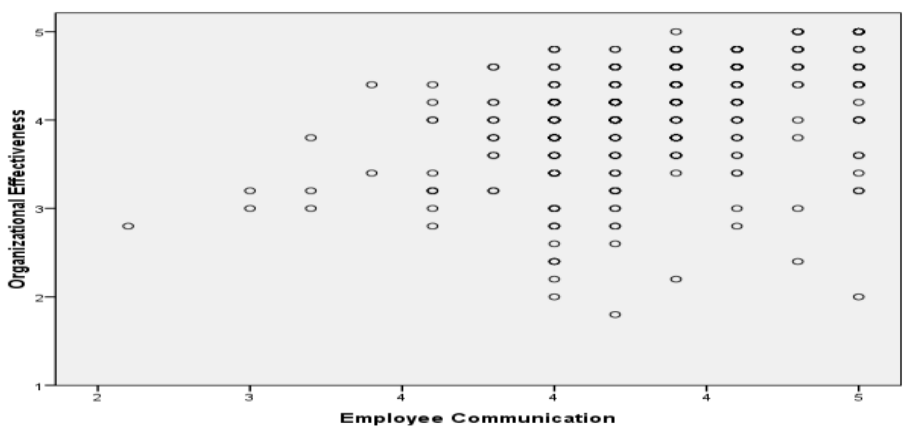

Fig: Scatter Plot of Perceived employee communication and organizational effectiveness Scores

Source: Author's Fieldwork Computation, 2017

\section{Test of Homoscedasticity and Linearity for Hypothesis Two}

From the output below, there appears to be a moderate, positive correlation among the variables. Respondents that are highly affected by talent availability experience high levels of organisational performance factors of employee retention. On the other hand, employees with less affected by talent availability have much higher levels of performance. There is no indication of a curvilinear relationship (test of linearity) and the scatter plot shows a fairly even cigar shape along its length (test of Homoscedasticity). 


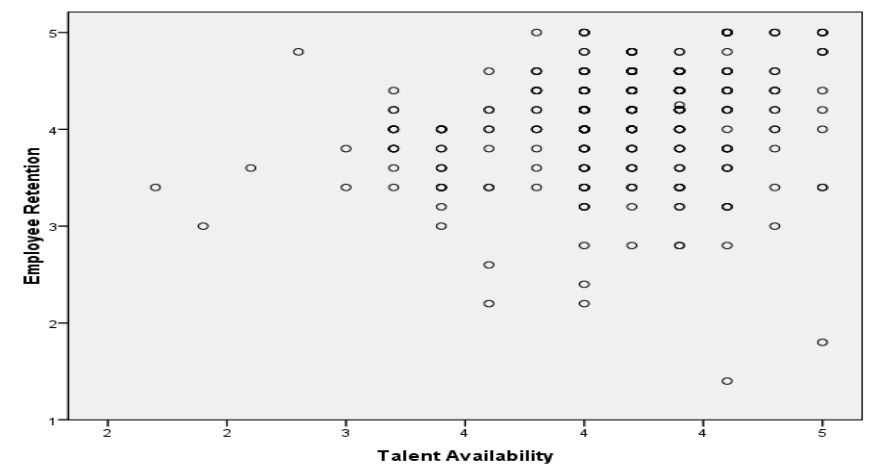

Fig 4.4.4.1.: Scatter Plot of talent availability and employee retention capacity Scores

Source: Author's Fieldwork Computation , 2017

\section{Test of Hypothesis One}

$\mathrm{Ho}_{1}$ : Employee communication does not significantly affect organizational effectiveness.

Standard multiple regression was used to explore the effects of employee communication variables does not significantly affect organizational effectiveness. Preliminary analyses were performed to ensure no violation of the assumptions of normality, Multicollinearity, homoscedasticity and linearity.

\section{Table 4.4.3.1}

\begin{tabular}{|l|l|r|r|r|r|r|}
\hline \multicolumn{9}{|c|}{ ANOVA $^{\mathbf{b}}$} \\
\hline \multicolumn{1}{|l|}{ Model } & Sum of Squares & Df & Mean Square & F & \multicolumn{1}{c|}{ Sig. } \\
\hline \multirow{3}{*}{1} & Regression & 38.792 & 4 & 9.698 & 37.023. & $.000^{\text {a }}$ \\
\cline { 2 - 8 } & Residual & 95.610 & 365 & .262 & & \\
\cline { 2 - 8 } & Total & 134.402 & 369 & & & \\
\hline
\end{tabular}

a. Predictors: (Constant), employee communication, employee training, team work, and effective communication

b. Dependent Variable: Organisational Effectiveness

Author's Fieldwork Computation, 2017

Also, the result of regression as contained in Table 4.4.3.2: Model Summary, shows that the R Square gave a large value of 28.9 per cent. This means that the model (which include employee communication, employee training, team work and effective communication) explained about 28.9 per cent of the variance in perceived organizational effectiveness.

Table 4.4.3.2

\begin{tabular}{|c|r|r|r|r|}
\hline \multicolumn{5}{|c|}{ Model Summary } \\
\hline Model & $\mathrm{R}$ & R Square & $\begin{array}{c}\text { Adjusted R } \\
\text { Square }\end{array}$ & $\begin{array}{c}\text { Std. Error of the } \\
\text { Estimate }\end{array}$ \\
\hline $.537^{\mathrm{a}}$ & .289 & .281 & .512 & $.537^{\mathrm{a}}$ \\
\hline
\end{tabular}

a. Predictors: (Constant), employee communication, employee training, team work and effective communication

Author's Fieldwork Computation, 2017

Specifically, the result of regression as contained in Table 4.4.3.3 Regression Coefficients, tests the hypotheses of this study. From the output below, there was positive relationship between perceived employee communication and perceived organisational effectiveness such that a unit increase in perceived employee communication scores caused about 322 unit increase in perceived organisational effectiveness scores which was statistically significant at 1 per cent withthe aid of the $\mathrm{p}$ value (0.000). Based on the result, the null hypothesis is rejected; thus, there was positive relationship between employee communication and organisational effectiveness.

Also, although, there was positive relationship between perceived employee training and perceived organisational effectiveness such that a unit rise in perceived employee training scores induced about .113 unit rise in perceived 
organisational effectiveness scores which was statistically not significant at 1 per cent going by the $p$ value (0.114). Based on the result, the null hypothesis is accepted; thus, employee training is not affected by organisational effectiveness. More importantly, there was positive relationship between perceived team work and perceived organisational effectiveness such that a unit rise in perceived team work scores induced about .261 unit rise in perceived organisational effectiveness scores which statistically significant at 1 per cent going by the $\mathrm{p}$ value (0.000). Based the result, the null hypothesis is rejected; thus, there was relationship between team work and organisational effectiveness.

Furthermore, there was positive relationship between perceived effective communication and perceived organisational effectiveness such that a unit rise in perceived effective communication scores induced about 227 unit rise in perceived organisational effectiveness scores which was statistically not significant at 1 per cent going by the $\mathrm{p}$ value (0.001). Based on the result, the null hypothesis is accepted; thus there was relationship between effective communication and organisational effectiveness.

Table 4.4.3.3

\begin{tabular}{|c|c|c|c|c|c|c|}
\hline \multicolumn{7}{|c|}{ Coefficients $^{\mathrm{a}}$} \\
\hline \multirow{2}{*}{\multicolumn{2}{|c|}{ Model }} & \multicolumn{2}{|c|}{ Unstandardized Coefficients } & \multirow{2}{*}{$\begin{array}{c}\begin{array}{c}\text { Standardized } \\
\text { Coefficients }\end{array} \\
\text { Beta } \\
\end{array}$} & \multirow[t]{2}{*}{$\mathrm{T}$} & \multirow[t]{2}{*}{ Sig. } \\
\hline & & B & Std. Error & & & \\
\hline \multirow[t]{5}{*}{1} & (Constant) & 240 & .336 & & .715 & .475 \\
\hline & Employee Communication & .322 & .081 & .209 & 3.951 & .000 \\
\hline & Employee training & .113 & .071 & .083 & 1.583 & .114 \\
\hline & Team work & .261 & .063 & .223 & 4.139 & .000 \\
\hline & Effective communication & .227 & .069 & .180 & 3.297 & .001 \\
\hline \multicolumn{3}{|c|}{ a. Dependent Variable: Organisational Effectiveness } & & & & \\
\hline
\end{tabular}

Author's Fieldwork Computation, 2017

\section{Test of Hypothesis Two}

$\mathrm{Ho}_{2}$ : There is no significant effect of talent availability on employee retention.

Standard multiple regression was used to explore the effects of monetary incentives, talent availability, talent loss and labour turnover on employee retention. The result of regression as contained in Table 4.4.4.1: ANOVA, shows that the F-test was 25.500, significant at 1 percent $[p<.000]$. This showed that the model was well specified.

Table 4.4.4.1

\begin{tabular}{|c|c|c|c|c|c|c|}
\hline \multicolumn{7}{|c|}{ ANOVA $^{\text {b }}$} \\
\hline \multicolumn{2}{|c|}{ Model } & Sum of Squares & Df & Mean Square & $\mathrm{F}$ & Sig. \\
\hline \multirow[t]{3}{*}{1} & Regression & 23.060 & 4 & 5.765 & 25.500 & $.000^{\mathrm{a}}$ \\
\hline & Residual & 82.517 & 365 & .226 & & \\
\hline & Total & 105.577 & 369 & & & \\
\hline
\end{tabular}

Author's Fieldwork Computation, 2017

Also, the result of regression as contained in Table 4.4.4.2: Model Summary, shows that the R Square gave a large value of 21.8 per cent. This means that the model (which includes Monetary Incentive, Talent Availability, Talent Loss, Labour Turnover) explained about 21.8 per cent of the variance in perceived employee retention. 
Table 4.4.4.2

\begin{tabular}{|l|c|c|c|c|}
\hline \multicolumn{5}{|c|}{ Model Summary } \\
\hline Model & $\mathrm{R}$ & R Square & $\begin{array}{c}\text { Adjusted R } \\
\text { Square }\end{array}$ & $\begin{array}{c}\text { Std. Error of the } \\
\text { Estimate }\end{array}$ \\
\hline 1 & $.467^{\mathrm{a}}$ & .218 & .210 & .475 \\
\hline \multicolumn{5}{|l}{$\begin{array}{l}\text { a. Predictors: (Constant), Monetary Incentive, Talent Availability, Talent } \\
\text { Loss, Labour Turnover }\end{array}$} \\
\hline
\end{tabular}

Author's Fieldwork Computation, 2017

Specifically, the result of regression as contained in Table 4.4.4.3.: From the output below, there was no positive relationship between perceived monetary incentives and employee retention capacity such that a unit increase in perceived monetary incentives scores caused about .155 unit decreases in perceived employee retention capacity score which was statistically not significant at 1 per cent with the aid of the p value (0.041). Based on the result, the null hypothesis accepted; thus, there was no relationship between monetary incentives and employee retention.

Also, although, there was positive relationship between perceived talent availability and perceived employee retention capacity such that a unit rise in perceived talent availability scores induced about .032 unit rise in perceived employee retention scores which was statistically significant at 1 per cent going by the $\mathrm{p}$ value $(0.002)$. Based on the result, the null hypothesis is rejected; thus talent availability affected employee retention. More importantly, relationship between talent loss and perceived employee retention was shown such that a unit rise in perceived talent loss scores induced about 291 unit increases in perceived employee retention capacity scores which is statistically significant at 1 per cent going by the $\mathrm{p}$ value $(0.000)$. Based the result, the null hypothesis is rejected; thus, there was relationship between talent loss and employee retention.

Furthermore, there was positive relationship between perceived labour turnover and perceived employee retention capacity such that a unit rise in perceived labour turnover scores induced about .220 unit rise in perceived employee retention capacity scores which was statistically significant at 1 per cent going by the $p$ value $(0.001)$. Based on the result, the null hypothesis is rejected; thus labour turnover affects perceived employee retention.

Table 4.4.4.3

\begin{tabular}{|c|c|c|c|c|c|c|}
\hline \multicolumn{7}{|c|}{ Coefficients $^{\mathrm{a}}$} \\
\hline \multicolumn{2}{|c|}{ Model } & \multicolumn{2}{|c|}{ Unstandardized Coefficients } & \multirow{2}{*}{$\begin{array}{c}\begin{array}{c}\text { Standardized } \\
\text { Coefficients }\end{array} \\
\text { Beta }\end{array}$} & \multirow[t]{2}{*}{$\mathrm{T}$} & \multirow[t]{2}{*}{ Sig. } \\
\hline & & $\mathrm{B}$ & Std. Error & & & \\
\hline \multirow[t]{5}{*}{1} & (Constant) & 1.493 & .312 & & 4.785 & .000 \\
\hline & Monetary Incentives & .155 & .076 & .114 & 2.055 & .041 \\
\hline & Talent Availability & .032 & .066 & -.026 & -.477 & .002 \\
\hline & Talent Loss & .291 & .059 & .280 & 4.971 & .000 \\
\hline & Labour Turnover & .220 & .064 & .197 & 3.447 & .001 \\
\hline & dent Variable: Emplo & & & & & \\
\hline
\end{tabular}

Author's Fieldwork Computation, 2017

\subsection{Discussion of Findings}

The finding has shown that there exist a positive relationship between influence of employee communication in reducing conflicts for effective management of workforce diversity and organizational effectives. It indicates that when employee communication increases, organizational effectiveness increases and vice versa. Open communication among the employees and top management helps increase the organisational effectiveness. This is consistent with the findings of NIWGW (2011) who suggested that the practice of open-door communication where employees can feel free to go to meet seniors for advice and guidance increases organizational effectiveness. 
In other words this research finding is tangential to past findings of scholars that have discovered that employee communication and its procedures have the tendencies to raise the level of organisation effectiveness. The positive relationship and effect between talent availability and employee retention depicts that as talent availability increases, employee retention also increases. When talents with diverse workforce are readily available in the organisation it helps bring about increase in their retention. This is in line with the findings of Vorhauser-Smith, 2012 which affirmed that continued education investment has to be one of the India's national development strategy and priority. Short of such public investment, India will not be able to bridge its skill shortage. While the Indian institutes of management (IIMs) enjoy high academic reputation around the world, its annual output of 1,740 graduates cannot meet the demand of India Inc. which requires 2,735, additional managers each year for example. Hence, talent availability has the tendencies to improve employee retention.

\section{Conclusions and Recommendations}

The study concluded that Workforce diversity represents both a challenge and an opportunity for business and corporate entity. In addition a growing number of progressive organizations are realizing the needs for valuing diversity in the workforce, so as to ensure strategic utilization of human resources for the accomplishment of strategic goals. Hence no organization this dispensation of globalization would survive without workforce diversity. The study recommended that Managers need to communicate more to employees, to give the workers the room to confide in them with their challenges. Managers should also be prepared to change some part of their company techniques when the diversity management techniques adopted are not working effectively but before doing so, the vision for the change must be communicated effectively. Moreover, managers should adopt some change management principles to guide them on the decision making of the change.

\section{References}

[1] Alysa, G. (2005). 12 secrets of effective business communication. Posted in HW to's - 35 comment by Noupe.

[2] Armstrong C. , Flood P, Guthirie P, Liu W, Maccurtain S, \&Mkamwa T, (2010). 'The Impact of Diversity and Equality Management On Firm Performance: Beyond High Performance Systems", Human Resource Management Journal, 49(6), 977-998

[3] Bagshaw, M, (2004) "Is diversity divisive?” Journal of Industrial and Commercial training, 36(4) 153-157.

[4] Bryan, J.H (1999). "The diversity imperative”, executive excellence, 6.

[5] Cox, T.H \& Blake, S (1991) managing cultural diversity: Implications for Organisational competitiveness academy of management executive, 5(3), 45-46.

[6] Crowe, M (1997) Open Communication: Key to Success of Diverse Workplace.Silicon Valley/ San Jose Business Journal.

[7] Ford, C. M. (1996). A theory of individual creative action in multiple social domains. Academy of Management Review, 21: 1112-1142.

[8] French, W. \& Bell, C.H (1983) Organisational Development ( $2^{\text {nd }}$ Ed.) Prentice Hall, New Delhi.

[9] Guzzo, R.A \& Dickson, M.W,(1996) Teams in organisations: Recent research on performance and effectiveness. Annual review of psychology, 47(1), 307-338

[10] Holt, M (2010) Challenges of Diversity Management. Retrieved from http://smallbusiness.chron.com/challengesdiversity-management-3044.html

[11] Horwitz, F.M, Heng, C.T \&Quazi, H.A (2003). Finders, keepers? Attracting, motivating and retaining knowledge workers. Hum Res Manage J, 13(4): 23-44.

[12] Jain, H.C \&Verma, A.(1996). Managing workforce diversity for competitiveness, The Canadian experience. International Journal of Manpower, 17(4/5): 14-29.

[13] Jayne, M.E \&vDipboye, R.L (2004) Leverage of diversity to improve business performance: Research findings and Recommendations for organisations-Human Resource management, 43(4): 409-424.

[14] Mayhen, $\mathrm{R}$ (2010). Communication and Diversity in the Workplace. Retrieved from http://smallbusiness.chron.com/challenges-diversity-workplace-1389.html

[15] National Integration Working Group for Workplaces (NIWGW),(2011). Managing Workplace Diversity: A tool kit for organisations.

[16] Office of State Personnel (OSP).(2008). Diversity management initiatives. Retrieved from http://www.performancesolutions.nc.org/developmentinitiatives/diversitymanagement/diversitymanagementinitiatives/i ndex.asp 